American Journal of Biochemistry \& Biotechnology 1 (3): 176-179, 2005

ISSN 1608-4217

(C) 2005 Science Publications

\title{
Influence of Rhizobacterial Inoculation on Growth of the Sweetpotato Cultivar
}

\author{
Farzana, Y. and Radizah, O. \\ Faculty of Agriculture, University Putra Malaysia, 43400 UPM Serdang, Selangor, Malaysia
}

\begin{abstract}
Sweetpotato (Ipomoea batatas L.) is the most important of local tuber crops in Malaysia. It is usually planted on marginal soils such as peat and sandy soils. Malaysian consumes a lot of sweetpotato and its production requires high fertilizer input, which can lead to increased production cost and environment problems. The use of bio-fertilizer and bioenhancer such as $\mathrm{N}_{2}$ (nitrogen) fixing bacteria and beneficial micro-organism can reducechemical fertilizer applications and consequently lower production cost. The pot experiment was conducted to determine the influence of rhizobacterial isolates on the response of sweetpotato plant growth. A total of five rhizobacterial isolates capable of producing indole-3-acetic acid (IAA) were used. Four of the isolates were collected from sweetpotato rhizosphere and one isolate was imported. Cuttings of sweetpotato cultivars melaka and oren were planted in plasticpots containing alluvium soil. Cultures of the rhizobacterial isolates were inoculated at planting time, two and four weeks after planting. Plants were harvested 60 days after planting. The results showed that, three of isolates significantly increased the plant growth and the N, P, K, Ca and $\mathrm{Mg}$ uptake of sweetpotato cultivar.
\end{abstract}

Key words: Melaka and oren, sweetpotato veriety, influence of rhizobacterial inoculation

\section{INTRODUCTION}

Sweet potato is one of the root crops that belong to the family convolvulaceae. It is an inexpensive source of energy, carotene, ascorbic acid, niacin, riboflavin, thiamine and minerals. In Malaysia, sweetpotato has been planted for more than 10 years and hundreds of sweetpotato varieties are available in the country. The commercial production of sweetpotato requires high inputs of chemical fertilizers, but high chemical fertilization could increase cost of crop and can lead to environmental problems. The use of beneficial microorganisms such as PGPR can reduce the cost of production and chemical fertilizers use. The PGPR has been found to produce the plant growth regulators which are auxin, cytokinin, gibberelin, ethylene and

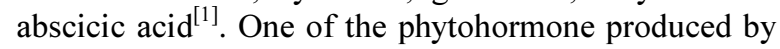
many species of bacteria is indole-3-acetic acid (IAA) which is an important hormone for plant growth and development. Generally micro-organism isolated from the rhizosphere and rhizoplane of various crops have revealed more potential of auxin production than those from the root free $\operatorname{soil}^{[2-4]}$. Significant increase in growth and yield of agronomically importants crops in response to inoculation with PGPR have been reported $^{[5-10]}$. Azospirillum and other bacteria were found to be a potential bio-fertilizer for sweetpotato as it increased yield ${ }^{[11]}$. However, PGPR inoculation has been shown to successfully enhance mineral uptake in root crops $^{[12]}$.Inoculation of plants with beneficial micro-organisms is one of the methods to increase the plant growth and yield .Many rhizobacteria are present in the soil, only certain species are able to improve plant growth. Therefore the aim of this study was undertaken to determine the influence of rhizobacterial isolates on the response of sweetpotato plant growth.

\section{MATERIALS AND METHODS}

Plant preparation: Rhizobacterial isolates capable of producing indole-3-acetic acid (IAA) were used. Rhizobacterial isolates were collected from sweetpotato rhizosphere, one isolate Azospirillum was originally provided by Dr. J. Dobereiner, EMBRAPA, Brazil. Sweetpotato cuttings of cultivars Melaka and Oren were cleaned using sterilized water and dipped into 10 $\mathrm{mL}$ of Kings $\mathrm{B}$ and Okon media broth containing $10^{8}$ $10^{10} \mathrm{cfu} \mathrm{mL}^{-1}$ for $20 \mathrm{~min}$.

Soil preparation and treatment: Two Kilogram of alluvium soil was placed into plastic pot. Inorganic fertilizer (N, P and K) in the forms of Urea, Triple Super Phosphate and Muriate of Potash applied once before planting at the rate of $30 \mathrm{~N}, 30 \mathrm{P}_{2} \mathrm{O}_{5}$ and $70 \mathrm{k}_{2} \mathrm{O} \mathrm{kg}$ $\mathrm{ha}^{-1}$, respectively. Sweetpotato cuttings which had been inoculated with the different isolates were then planted one plant per pot in the respective pots. Cultures of rhizobacterial isolates were grown in Kings B media broth and Azospirillum in Okon media broth ${ }^{[13]}$. Ten milliliters of the culture with approximately $10^{8}-10^{10} \mathrm{cfu}$ $\mathrm{mL}^{-1}$ were inoculated at planting time, two and four weeks after planting. The pot experiment was arranged in a Randomized Complete Design with three replications. The treatments for each cultivar were $T_{1}$ :

Corresponding Author: Farzana, Y., Faculty of Agriculture, Universiti Putra Malaysa, 43400 UPM Serdang, Selangor, Malaysia 
Control, $\mathrm{T}_{2}$ : UPMSP6, $\mathrm{T}_{3}$ : UPMSP8, $\mathrm{T}_{4}$ : UPMSP9, $\mathrm{T}_{5}$ : UPMSP18, $\mathrm{T}_{6}$ : Azospirillum brasilenseSP7. Plants were watered daily to field capacity and harvested 60 days after planting. Plant tops were cut $1 \mathrm{~cm}$ from the base, the roots were washed off soil using distill water. The plants parts were then dried in the oven at $70^{\circ} \mathrm{c}$ for 48 hour. The dry weight measured till a constant weight was reached. Dried shoot samples were ground using mechanical grinder with $0.5 \mathrm{~m} . \mathrm{m}$ sieve and digested by concentrated sulphuric acid $\left(\mathrm{H}_{2} \mathrm{SO}_{4}\right)$ and hydrogen peroxide $\left(\mathrm{H}_{2} \mathrm{O}_{2}\right)$ using Block Digestion following the Kjeldhal method ${ }^{[14]}$. N, P and K. were determined using an Auto Analyzer (AA) and Atomic Absorption Spectrophotometer(AAS) for $\mathrm{Ca}$ and $\mathrm{Mg}$.

\section{RESULTS}

Melaka Cultivar: The results showed that plant inoculation with the bacterial isolates were significant affect on plant growth. The Dry wt. of shoots varied with the inoculation treatment .Most of the inoculated plants showed positive plant growth compared to the non-inoculated plants. Dry wt. of shoots inoculated with UPMSP9 was significantly higher than control. The highest root dry wt. was found on plant inoculated with UPMSP18 followed by UPMSP9 compared to the non-inoculated plant. Plants inoculated with UPMSP6 showed the lowest root dry wt. (Table 1).

Table 1: Plant growth of sweetpotato (melaka cultivar) plants inoculated with rhizobactera

\begin{tabular}{lll}
\hline Treatments & $\begin{array}{l}\text { Shoot Dry Wt. } \\
\text { g plant }^{-1}\end{array}$ & $\begin{array}{l}\text { Root Dry Wt. } \\
\text { g plant }^{-1}\end{array}$ \\
\hline Control & $6.25 \mathrm{c}$ & $1.78 \mathrm{~b}$ \\
UPMSP6 & $8.45 \mathrm{ab}$ & $1.83 \mathrm{~b}$ \\
UPMSP8 & $8.55 \mathrm{ab}$ & $2.02 \mathrm{ab}$ \\
UPMSP9 & $9.34 \mathrm{a}$ & $2.14 \mathrm{ab}$ \\
UPMSP18 & $6.95 \mathrm{bc}$ & $2.23 \mathrm{a}$ \\
Azospirillum SP7 & $7.06 \mathrm{bc}$ & $2.00 \mathrm{ab}$ \\
\hline
\end{tabular}

Note: Mean values with the same letter were not significantly

different at $\mathrm{P}<0.05$, according to Duncan's Multiple Range Test
The uptake of $\mathrm{N}, \mathrm{P}, \mathrm{K}$ and $\mathrm{Ca}$ in plant tops were significantly affected by inoculation treatments. The uptake of $\mathrm{N}$ was significantly high in plants inoculated withUPMSP8 and followed by UPMSP9. The highest values of $K$ and $P$ uptake were found in plants inoculated withUPMSP8 followed by UPMSP9 (Table 2). For Ca higher uptake was found in plants inoculated of UPMSP6 followed by Azospirillium and UPMSP9. These results are indicated that insignificant effect of inoculation of rhizobacterial isolates on the uptake of $\mathrm{Mg}$ in plant shoots of sweetpotato. In general, plants inoculated with UPMSP8, UPMSP9 and Azospirillium seemed to positively increase the growth of shoot and root and the content of plant nutrients in plant shoots.

Oren cultivar: The results showed that dry wt. of shoots were significantly affected by inoculation treatment. Inoculation with UPMSP9 showed high shoot dry wt. followed by Azospirillium. There was no significant effect of inoculation of rhizobacterial isolates for dry wt. of roots. The high dry wt. of roots was shown on plants inoculated of Azospirillium (Table 3).

There was no significant effect of inoculation with rhizobacterial isolates on the uptake of $\mathrm{N}$ and $\mathrm{P}$ in plant shoots of sweetpotato. The high uptake of $\mathrm{N}$ was shown on plants inoculated with UPMSP8and followed by UPMSP9. Inoculation with Azospirillium and followed by UPMSP9 also showed the highest uptake of P. Inoculation of plant with the rhizobacterial isolates significantly increased the content of $\mathrm{K}, \mathrm{Ca}$ and $\mathrm{Mg}$ in plant tissue. Plants inoculated with Azospirillium highest content of $\mathrm{K}$ and $\mathrm{Ca}$ in tissue. Inoculation of UPMSP8 showed high uptake of $\mathrm{Mg}$ followed by UPMSP9 (Table 4).

Table 2: The Effects of rhizobacterial isolates inoculation on nutrient uptake of sweetpotato (melaka cultovar)

\begin{tabular}{|c|c|c|c|c|c|}
\hline Treatments & $\mathrm{N}$ uptake $\mathrm{mg}_{\text {plant }}{ }^{-1}$ & $\mathrm{P}$ uptake $\mathrm{mg}_{\text {plant }}{ }^{-1}$ & $\mathrm{~K}_{\text {uptake } \mathrm{mg} \text { plant }}{ }^{-1}$ & Ca uptake mg plant ${ }^{-1}$ & Mg uptake mg plant ${ }^{-1}$ \\
\hline Control & $43.61 \mathrm{~b}$ & $17.29 \mathrm{~b}$ & $57.42 \mathrm{c}$. & $64.89 \mathrm{c}$ & $23.90 \mathrm{a}$ \\
\hline UPMSP6 & $89.67 \mathrm{ab}$ & $24.82 \mathrm{a}$ & $85.76 b$ & $112.60 \mathrm{a}$ & $36.54 \mathrm{a}$ \\
\hline UPMSP8 & $129.03 a$ & $25.43 a$ & $111.94 \mathrm{a}$ & $97.34 \mathrm{ab}$ & $36.37 \mathrm{a}$ \\
\hline UPMSP9 & $112.34 \mathrm{a}$ & $24.00 \mathrm{a}$ & $89.36 b$ & $99.71 \mathrm{ab}$ & $26.28 \mathrm{a}$ \\
\hline UPMSP18 & $76.55 \mathrm{ab}$ & $17.47 \mathrm{~b}$ & $76.97 b$ & $85.09 \mathrm{~b}$ & $25.77 \mathrm{a}$ \\
\hline Azospirillum SP7 & $74.49 \mathrm{ab}$ & $18.39 \mathrm{~b}$ & $88.55 b$ & $103.97 \mathrm{ab}$ & $27.22 \mathrm{a}$ \\
\hline
\end{tabular}

Note: Mean values with the same letter were not significantly different at $\mathrm{P}<0.05$, according to Duncan's Multiple Range Test

Table 3: Plant growth of sweetpotato (oren cultivar) plants inoculated with rhizobactera

\begin{tabular}{lcc} 
Treatments & $\begin{array}{c}\text { Shoot Dry Wt. } \\
\text { g plant }^{-1}\end{array}$ & $\begin{array}{l}\text { Root Dry Wt. } \\
\text { g plant }^{-1}\end{array}$ \\
\hline Control & $6.87 \mathrm{~b}$ & $2.96 \mathrm{a}$ \\
UPMSP6 & $8.87 \mathrm{a}$ & $3.40 \mathrm{a}$ \\
UPMSP8 & $8.65 \mathrm{a}$ & $3.05 \mathrm{a}$ \\
UPMSP9 & $9.47 \mathrm{a}$ & $3.09 \mathrm{a}$ \\
UPMSP18 & $9.03 \mathrm{a}$ & $3.25 \mathrm{a}$ \\
Azospirillum SP7 & $9.41 \mathrm{a}$ & $3.42 \mathrm{a}$ \\
\hline
\end{tabular}

Note: Mean values with the same letter were not significantly different at $\mathrm{P}<0.05$, according to Duncns Multiple Range Test 
Am. J. Biochem. \& Biotech. 1 (3): 176-179, 2005

Table 4: The effects of rhizobacterial isolates inoculation on nutrient uptake of sweetpotato (oren cultovar)

\begin{tabular}{|c|c|c|c|c|c|}
\hline Treatments & $\mathrm{N}$ uptake mg plant ${ }^{-1}$ & P uptake mg plant ${ }^{-1}$ & $\mathrm{~K}_{\text {uptake mg plant }}{ }^{-1}$ & Ca uptake mg plant ${ }^{-1}$ & Mg uptake mg plant ${ }^{-1}$ \\
\hline Control & $83.85 \mathrm{a}$ & $18.15 \mathrm{a}$ & $93.11 \mathrm{~b}$ & $68.71 \mathrm{~d}$ & $29.66 b$ \\
\hline UPMSP6 & $101.51 \mathrm{a}$ & $22.07 \mathrm{a}$ & $122.29 b$ & $108.12 b c$ & $39.12 \mathrm{ab}$ \\
\hline UPMSP8 & $122.64 a$ & $23.96 a$ & $108.10 \mathrm{~b}$ & $111.80 \mathrm{~b}$ & $43.75 \mathrm{a}$ \\
\hline UPMSP9 & $112.20 \mathrm{a}$ & $24.30 \mathrm{a}$ & $113.95 b$ & $92.22 b c$ & $43.23 \mathrm{a}$ \\
\hline UPMSP18 & $108.98 \mathrm{a}$ & $22.50 \mathrm{a}$ & $112.96 \mathrm{~b}$ & $89.07 \mathrm{~cd}$ & $30.94 b$ \\
\hline Azospirillum SP7 & $109.76 \mathrm{a}$ & $25.89 \mathrm{a}$ & $161.35 \mathrm{a}$ & $139.65 a$ & $33.3 \mathrm{ab}$ \\
\hline
\end{tabular}

Note: Mean values with the same letter were not significantly different at $\mathrm{P}<0.05$, according to Duncan's Multiple Range Test

\section{DISCUSSION}

Inoculation of sweetpotato cultivar with rhizobacterial isolates significantly increased the shoot dry weight .the high shoot dry wt. in plants inoculated with UPMSP9 could be due to the ability of the bacteria to produce IAA and other metabolic activities. According to ${ }^{[4]}$, inoculated rhizobacteria significantly affect plant growth by increasing nutrient uptake, suppressing pathogens by producing antibiotics and siderophores or bacterial and fungal antagonistic substances and/or by producing biologically active substances such as auxins and other plant hormones. The result in the study was not definitive as plants were grown for only 60 days, which is at the initiation stage of storage root development.

The beneficial effect could be confirmed when root yield is obtained at 4 months of growth. Although sweetpotato was grown for 60 days, the study showed that rhizobacterial Inoculation was able to positively influence plant growth.

The ability of the isolates to produce IAA could be one of the mechanisms in stimulating plant growth. The IAA has been known to stimulate cell enlargement, stem growth, root initiation on stem cuttings and the development of branch roots ${ }^{[15]}$. The formation and yield of storage root was found to be promoted by good formation of roots ${ }^{[16]}$. Azospirillium is one type of bacteria that is able to produce IAA. The bacteria has been used in production of various crops including sweetpotato. Saad et al. ${ }^{[11]}$ found that plants grown on sandy tin tailing inoculated with Azospirillium produced higher yield than those without Azospirillium and fertilizer. Inoculation with Azospirillium also decreased rate of $\mathrm{N}$ fertilizer. The beneficial effect could probably be due to production of phytohormone and $\mathrm{N}_{2}$ fixation by the bacteria.

The rhizobacterial Inoculation on sweetpotato plants showed various effects on nutrient content in tissue of sweetpotato tops. In Melaka cultivar, there were differences in the contents of N,P,K and $\mathrm{Ca}$ between treatments, the differences were significant, on the other hand uptake of $\mathrm{Mg}$ in plant shoots were not significant . In Oren cultivar, uptake of $\mathrm{N}$ and $\mathrm{P}$ in plant shoots were not significant .Most of the nutrients were being taken up by plants at almost the same rate but it could probably differ during translocation of nutrients to the development of storage root at later plant age.
In general, the nutrient content in tissue was positively correlated with shoot and root dry weights. The increased dry weights of shoot and fibrous root could increase the uptake of minerals and leading to increased in the content of nutrient in plant. Profuse fibrous root growth at the initial plant growth could probably stimulate the rhizobacteria to colonize on the root surface and improve the plant nutrient uptake.

\section{CONCLUSION}

The rhizobacterial strains isolated from sweetpotato rhizosphere were able to increase the initial growth of sweetpotato plant cultivar Melaka and Oren in the pot experiment. The increase in root dry wt. of Melaka cultivar could probably increase tuberization. There was a potential of utilizating the rhizobacterial isolates as plant inoculant for production of sweetpotato storage roots

\section{REFERENCES}

1. Arteca Richard, N.,1996. Plant Growth Substances. Principles and Applications. Chapman and Hall. New York.

2. Sarwar, M. and R.J. Kremer, 1995a. Determination of bacterially derived auxins using a microplate method. Lett. Appl. Microbiol., 20: 282-285.

3. Sarwar, M. and R.J. Kremer, 1995b. Enhanced suppression of plant growth through production of L-tryptophan-derived compounds by deleterious rhizobacteria. Plant and Soil, 172: 261-269.

4. Arshad, M. and W.T.Jr. Frankenberger, 1998. Plant growth regulating substances in the rhizosphere: Microbial production and functions. Adv. Agron., 62: 146-151.

5. Chen, Y., R. Mei, S. Lu, L. Liu and J.W. Klopper, 1994. The use of yield increasing bacteria as plant growth promoting rhizobacteria in Chinese agriculture. In Management of Soil Born Diseases sd. Gupta, V.K. and Utkhede, R. pp: 1-13. New Hehli, India: M/S Narosa Pub. House.

6. Amara, M.A.T. and M.S.A. Dohdoh, 1997. Effect of inoculation with plant growth promoting rhizobacteria (PGPR) on yield and uptake of nutrients by wheat growth on sandy soil. Egyptian J. Soil Sci., 37: 467- 484.

7. Biswas, J.C., J.K. Ladha and F.B. Dazzo, 2000a. Rhizobia inoculation improves nutrient uptake and growth of lowland rice. Soil Sci. Soc. Am. J., 83: 880-886. 
8. Biswas, J.C., J.K. Ladha, F.B. Dazzo, Y.G. Yanni and B.G. Rolfe, 2000b. Rhizobial inoculation influences seedling vigor and yield of rice. Agron. J., 82: 1644-1650.

9. Hilali, A., D. Przrost, W.J. Broughton and A. Antoun, 2001. Effects de I'inoculation avec des souches de Rhizobium leguminosarum bv. Trifolii sur la croissance du bl'e dans deux sols du Marco. Can. J. Microbiol., 47: 590-593.

10. Asghar, H.N., Z.A. Zahir, M. Arshad and A. Khaliq, 2002. Relationship between in with production of auxins by rhizobacteria and their growth promoting activities in Brassica juncea. L. Biol. Fertility of Soils, 35: 231-237.

11. Saad, M.S., A.S.A. Sabuddin, A.G. Yunus and Z. Shamsuddin, 1996. Performance of sweetpotato variety UPMSS5 inoculated with Azospirillum brasilense on sandy tin tailing soil. 1st Asian Sweetpotato and Potato Research and Development Meeting, Indonesia, Aug., 27-30.

12. Kloepper, J.W., 1993. Plant growth promoting rhizobacteria as biological control agents. In Soil Microbial Ecology.(Ed., Metting, F.B. Jr.). MARCEL Dekker, Inc. New York, pp: 255-274.
13. Okon,Y., S.L. Albrecht and R.H. Burris, 1977. Methods for growing Spirillum lipoferum and for counting it in pure culture and different solution in association with plants. Appl. Environ. Microbiol., 33: 85-88.

14. Bremner, J.M., 1996. Nitrogen-Total. In Methods of Soil Analysis (Part3). Chemical Methods, Ed. Spark, D.L., Page, A.L., Helmke, P.A., Loeppert, R.H., Sultanpour, P.N., Tabatabai, M.A., Johnsto, C.T. and Sumner, M.E., pp: 1085-1121.Am. Soc. Agron., Inc., Madison, Wisconsin, USA.

15. Frankenberger, Jr.W.T and M. Arshad, 1995. Phytohormones in soils microbial production and function. Marcel Dekker, Inc. New York.

16. Ewing, E.E., 1987. The role hormones in potato (Solanum tuberosum L.) In Plant Hormone And Their Role In Plant Growth and Development. Martinus Nijhoff Publishers. Netherlands, pp: 515-538. 